\title{
Translation and cross-cultural adaptation of the Motor Behavior Checklist (MBC) into Brazilian Portuguese
}

\author{
Tradução e adaptação transcultural para o português do Brasil do Motor \\ Behavior Checklist (MBC)
}

\author{
Ronê Paiano, ${ }^{1}$ (D) Maria Cristina Triguero Veloz Teixeira, ${ }^{1}$ Carla Nunes Cantiere, ${ }^{1}$ Maria A. Efstratopoulou, ${ }^{2}$ \\ Luiz Renato Rodrigues Carreiro ${ }^{1}$
}

\begin{abstract}
Introduction: There are only a few instruments available to assess behavioral problems in school-age children based on reports of physical education teachers. The Motor Behavior Checklist (MBC) was designed to be completed by this professional in free play-situations or during physical education classes to rate students' motor-related behavior using 5-point Likert scales. The MBC comprises 59 items distributed into two broadband factors (externalizing and internalizing) and seven behavior problem scales: rule breaking, hyperactivity/impulsivity, lack of attention, low energy, stereotyped behaviors, lack of social interaction, and lack of self-regulation. The objective of this study was to describe the translation and cross-cultural adaptation processes of the MBC into Brazilian Portuguese.

Method: The following procedures were conducted: forward translation of the original instrument, production of a synthesized version, back-translation, literal and semantic comparison, back-translator's evaluation of divergent items, synthesized version with back-translator's suggestions, clarity assessment of the synthesized version by professionals (physical education teachers), focus group to assess clarity indicators of the instrument, evaluation of adjustments by the author of the instrument, and production of the final version.

Results: The results indicated a satisfactory level of agreement between the original and the back-translated versions, with $68 \%$ of exact equivalence between the translated items and $16 \%$ of terms requiring minor adjustments. In the draft version, $84 \%$ of the items were evaluated as clear by physical education teachers.

Conclusion: The translated version has compatible content with the original version. Future studies should be conducted to assess the psychometric properties of the Brazilian Portuguese version of the MBC.
\end{abstract}

Keywords: Motor behavior, children, physical education, attention, cross-cultural adaptation.

\section{Resumo}

Introdução: Existem poucos instrumentos disponíveis para avaliar problemas de comportamento em crianças em idade escolar com base no relato de professores de educação física. $O$ Motor Behavior Checklist (MBC) foi criado para ser usado por este profissional observando a criança em uma situação de brincadeira livre ou nas aulas de educação física utilizando escalas Likert de 5 pontos. O MBC compreende 59 itens distribuídos em duas categorias (externalizantes e internalizantes) e sete escalas de problemas de comportamento: quebra de regras, hiperatividade/ impulsividade, falta de atenção, baixa energia, comportamentos estereotipados, falta de interação social e falta de autorregulação. $\mathrm{O}$ objetivo deste estudo foi descrever o processo de tradução e adaptação transcultural do MBC para o português do Brasil.

Método: Os procedimentos foram: tradução do instrumento original, produção de uma versão sintetizada, retrotradução, comparação literal e semântica, parecer do retrotradutor sobre itens divergentes, versão síntese com as sugestões do retrotradutor, avaliação da clareza da versão síntese por profissionais (professores de educação física), grupo focal para avaliar indicadores de clareza do instrumento, avaliação dos ajustes pelo autor do instrumento e produção da versão final.

Resultados: Os resultados indicaram um nível satisfatório de concordância entre as versões originais e retrotraduzidas, com $68 \%$ de itens iguais e $16 \%$ de itens com poucas alterações. A versão síntese teve $84 \%$ dos itens avaliados como claros por professores de educação física.

Conclusão: A versão traduzida possui conteúdo compatível com a versão original. Estudos futuros deverão ser conduzidos para a verificação das propriedades psicométricas da versão em português brasileiro do MBC.

Descritores: Comportamento motor, crianças, educação física, atenção, adaptação transcultural.

\footnotetext{
${ }^{1}$ Programa de Pós-Graduação em Distúrbios do Desenvolvimento, Centro de Ciências Biológicas e da Saúde, Universidade Presbiteriana Mackenzie, São Paulo, $\mathrm{SP}$, Brazil. ${ }^{2}$ Department of Social Sciences, Bishop Grosseteste University, Lincoln, UK. Submitted Aug 23 2017, accepted for publication Nov 142018.

Suggested citation: Paiano R, Teixeira MCTV, Cantiere CN, Efstratopoulou MA, Carreiro LRR. Translation and cross-cultural adaptation of the Motor Behavior Checklist (MBC) into Brazilian Portuguese. Trends Psychiatry Psychother. 2019;41(2):167-175. http://dx.doi.org/10.1590/2237-6089-2017-0104
} 


\section{Introduction}

Neurodevelopmental disorders (NDD) are a group of disorders that typically manifest early in development, usually before the age at which children start school. NDD are characterized by developmental deficits that range from specific limitations of learning or control of executive functions to global impairments of social skills or intelligence. ${ }^{1}$ Parents/teachers are often asked to answer questions about the behavior of their children/ students during the assessment of developmental impairments and/or behavioral problems. This approach allows the collection of standardized information about child behavior in different environments and in natural conditions. Considering the school setting, most studies show that classroom teachers play a key role in providing information about a child's behavior. ${ }^{2-5}$

Only a few studies have assessed instruments that rely on physical education teachers as a main source of information about emotional, behavioral, and/ or developmental problems in school-age children. Although reports of physical education teachers could be used as a criterion to identify signs of NDD in children, the instruments aimed at these professionals are not considered as important sources of information for behavioral difficulties because they usually focus on movement and motor coordination problems. ${ }^{6}$ However, physical education classes and team games allow the naturalistic observation of several behavioral repertoires exhibited during social interactions, cooperative games, competitions, decision making and problem solving scenarios, and rule-following situations, among others. ${ }^{7,8}$ Therefore, physical education teachers could play a key role in assessing their students' behavior. ${ }^{6}$

Attention deficit hyperactivity disorder (ADHD) is one among the NDD that physical education teachers could help identify by gathering information about student behavior. During physical education classes, students are required to behave in a variety of ways; in the presence of ADHD, a child usually exhibits problems in executive functioning areas such as turn-taking, motor movement at varying levels (depending on the type of activity), cooperation, decision-making, and focusing on the same task for an extended period.

The Sports Behavior Checklist is a 29-item informant report measure developed to assess behavioral difficulties in children with ADHD. The instrument evaluates involvement in individual and team sports, addressing the length of participation, types of sports played, and quality of involvement. ${ }^{7}$ The remaining 26 items assess frequency of aggression, emotional reactivity, injury, disqualification, adherence to rules, and sportsman-like conduct. A study with boys aged
6-17 years - 34 with ADHD and 41 without ADHD showed higher levels of aggression, emotional reactivity, and frequency of disqualification in children with ADHD when compared to those without the disorder. However, both groups presented high levels of aggression and emotional reactivity when playing team sports compared to individual sports. ${ }^{7}$

Clendenin et al. ${ }^{8}$ verified the psychometric properties of the Sport Behavior Checklist in a sample of 5-13-yearold children composed of 58 boys and 34 girls, 49 with ADHD and 43 without ADHD. They also found higher levels of aggression, emotional reactivity, and frequency of disqualification in children with ADHD, similar to the results of the other study previously mentioned. ${ }^{7}$ Although the Sports Behavior Checklist is widely used to assess the behavior of children in sports settings, the instrument was not designed as a screening tool to identify different disorders during sports practice.

In this scenario, the Motor Behavior Checklist (MBC) for Children ${ }^{9}$ was developed with 59 items evaluating motor behavior distributed into two broadband factors - internalizing and externalizing behaviors - and seven behavior problem scales. Externalizing behaviors include rule-breaking ( 7 items), hyperactivity and impulsivity (14 items), and lack of attention (10 items). Internalizing behaviors include low energy (4 items), stereotyped behaviors ( 2 items), lack of social interaction (10 items), and lack of self-regulation (12 items). Many of these categories of behavioral problems can be observed in the form of both deficits and excesses in ADHD and autistic spectrum disorder (ASD). ${ }^{10}$ The MBC should be completed observing the child in a free-play situation or during physical education classes. The score is obtained through a 5-point Likert scale ranging from never (0) to almost always (4). Efstratopoulou et al. ${ }^{9}$ evaluated the psychometric properties of the MBC: coefficients of internal consistency (a) ranged from 0.82 to 0.95 , reproducibility according to intraclass correlation coefficients (ICC) ranged from 0.85 to 0.90 , and concordance (also ICC) ranged from 0.75 to 0.91 . These data suggest that the $M B C$ for children is a homogeneous instrument in terms of content, with high stability and correlation. ${ }^{9}$

The authors of that study ${ }^{9}$ evaluated 83 children with different diagnoses (ADHD, conduct disorder, learning disorders, and ASD) using physical education teachers as informants for the MBC. The instrument revealed that children with ADHD displayed more symptoms of hyperactivity and attention deficit, that children with conduct disorder had more problems related to breaking rules, that children with ASD showed more problems with stereotyped behaviors and lack of social interaction, and that children with learning disorders showed no significant differences in relation to the 
other groups. These results indicate that the MBC is a useful tool to discriminate between the core symptoms of ADHD, conduct disorder, and ASD. ${ }^{9}$

In another study, Efstratopoulou et al. ${ }^{10}$ examined the agreement among different instruments by assessing a group of students as follows: the MBC completed by the physical education teacher; the Teacher Report Form (TRF) and the ADHD Rating Scale-IV completed by the classroom teacher; and the parent's version of the Child Behavior Checklist $(\mathrm{CBCL})$ and the ADHD Rating Scale-IV completed by the parents. The authors found significant correlations with specific $M B C$ subscales and the corresponding subscales of the TRF, CBCL, and ADHD Rating Scale-IV. In particular, they found significant correlations for the rule breaking, lack of attention, hyperactivity/impulsivity, and lack of social interaction problem scales, and for the internalizing, externalizing, and total scores. In relation to the ADHD scale - more specifically lack of attention and hyperactivity/impulsivity scales -, the MBC items demonstrated convergent relationships with the ADHD Rating Scale-IV (teachers and parents), with greater correlations between physical educators and teachers than between physical educators and parents for both scales.

The MBC has also shown highly sensitive psychometric properties in the identification of ASD signs, ${ }^{9}$ a disorder characterized by persistent deficits in social communication and social interaction in multiple settings, including deficits in social reciprocity and nonverbal and verbal communication. In addition to deficits in social communication, the diagnosis of ASD requires the presence of restricted and repetitive patterns of behavior, interests, or activities. ${ }^{1}$

In social interaction settings with multiple stimuli, the behavioral patterns of children with ADHD and ASD can be more clearly expressed than in a classroom environment, where stimuli are tightly controlled and students are supposed to follow more rigid rules of behavior. Therefore, the MBC is an important tool both to assist physical education teachers in the process of referring students for a more detailed evaluation and to collect information from children and adolescents as part of the process of clinical investigation.

Although no consensus can be found in the literature on the steps for a cross-cultural adaptation process, scholars agree that this process must go beyond a simple translation, ${ }^{11,12}$ since a translation alone does not guarantee the reliability and construct validity of the instrument. ${ }^{11}$ Several steps are necessary to ensure a careful process of cross-cultural adaptation of an instrument. ${ }^{11-13}$ The first step consists of translating the document, which must be performed by more than one translator. ${ }^{11-13}$ While the translation as the first step is common to all works, the subsequent steps may be diverse.
Some studies propose a synthesis of the translated versions followed by a back-translation. ${ }^{12,14-16}$ It is also recommended that more than one back-translator be used, which may increase financial costs. ${ }^{12}$ The next step is the analysis by an expert panel and by target groups. ${ }^{12,14-16}$ Another possibility, as proposed by Borsa et al. ${ }^{11}$ is that the evaluation by experts and later by target groups be done before the back-translation process.

After these steps, some authors also suggest a pilot study to assess the need for adjustment of the instrument before the final application. ${ }^{11,12,14-16}$ Statistical analyses should be carried out in a complementary fashion to the cross-cultural adaptation process to evaluate the extent to which the instrument can, in fact, be considered valid for the setting to which it has been adapted. ${ }^{11,13}$

Mondrzak et al. ${ }^{14}$ used the guidelines proposed by the Task Force for Translation and Cultural Adaptation of the International Society for Pharmacoeconomics and Outcomes Research, which divides the translation process into 10 steps: preparation, forward translation, reconciliation of different translations into a single version, back-translation, back-translation review, harmonization, cognitive debriefing, review of cognitive debriefing results and finalization, proofreading, and final report.

Gjersing et al., ${ }^{12}$ in turn, performed a careful process of cross-cultural adaptation of a research instrument following 12 steps: investigation of conceptual and item equivalence, original instrument translation (by two fluent translators), compilation of a synthesized translated version (by a third translator), backtranslation (by two fluent translators), compilation of a synthesized back-translated version (by a third backtranslator), expert committee judgment, instrument pretest, revision of the instrument, investigation of operational equivalence, main study conduction, exploratory and confirmatory analysis, and final instrument consolidation.

Finally, Borsa et al. ${ }^{11}$ suggest a six-step process of cross-cultural adaptation: 1) translation of the instrument from the source language into the target language; 2) synthesis of translated versions; 3) synthesis evaluation by expert judges; 4) evaluation of the instrument by the target groups; 5) back-translation; and 6 ) pilot study. In addition to these six steps, the authors emphasize the importance of an assessment of the factorial structure of the instrument to confirm its stability in relation to the original document.

The objectives of the study were to describe the translation and cross-cultural adaptation processes of the MBC into Brazilian Portuguese and to present a validated version of the instrument in the target language. 


\section{Method}

The translation and cross-cultural adaptation processes adopted in this study followed the main recommendations described in the works previously mentioned, ${ }^{11-14}$ following 10 stages, which are described in sequential order in Figure 1 and Table 1.
The project was approved by the ethics committee of Universidade Presbiteriana Mackenzie (protocol 1886171, CAAE 61179416.8.0000.0084). We received the author's permission to translate and cross-culturally adapt the original version of the MBC into Brazilian Portuguese.

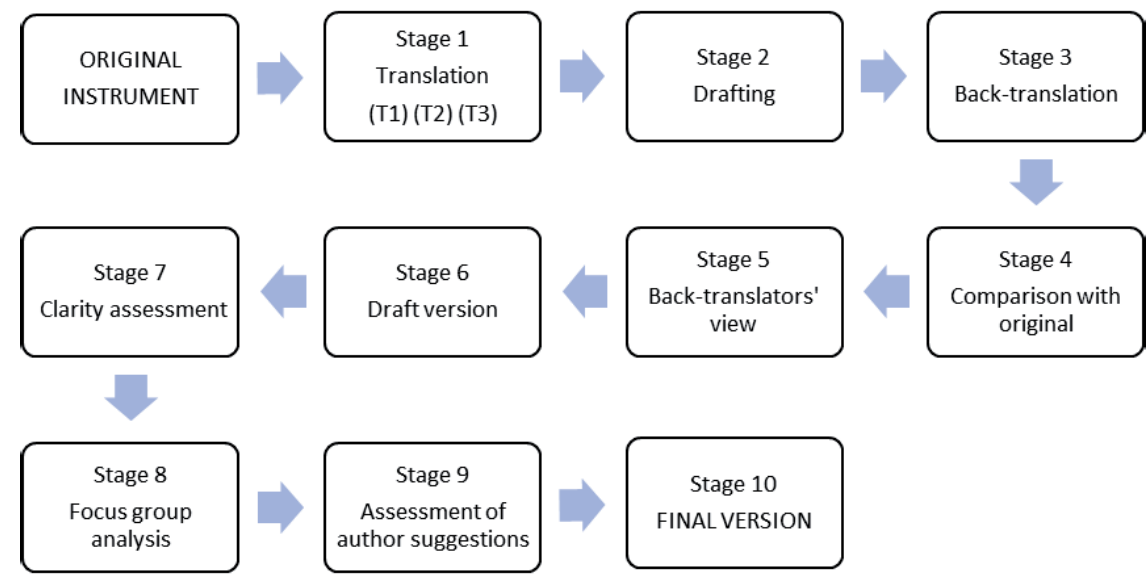

Figure 1 - Stages involved in the translation and cross-cultural adaptation processes of the Motor Behavior Checklist

Table 1 - Description of the translation and cross-cultural adaptation stages

\begin{tabular}{|c|c|}
\hline Stages & Actions \\
\hline 1 & $\begin{array}{l}\text { Three professionals with proficiency in English independently translated the instrument into Portuguese. } \\
\text { - Translator 1: psychologist with expertise in cognitive neuropsychology and associated neurodevelopmental disorders. } \\
\text { - Translator 2: psychologist with expertise in applied behavior analysis and identification/management of behavioral } \\
\text { problems in neurodevelopmental disorders. } \\
\text { - Translator 3: physical education teacher with experience in neurodevelopmental disorders. }\end{array}$ \\
\hline 2 & $\begin{array}{l}\text { After completion of the individual translations, the translators compared the different versions of each item to reach a } \\
\text { consensus, seeking the most appropriate cultural adjustment in case of discrepancies to facilitate understanding. }\end{array}$ \\
\hline 3 & $\begin{array}{l}\text { The instrument was back-translated into the source language by an English teacher with command of both English and } \\
\text { Portuguese, an English native speaker living in Brazil. }\end{array}$ \\
\hline 4 & $\begin{array}{l}\text { The original document was compared with the back-translated version in order to find the best literal and semantic match } \\
\text { between the words in the two versions. }\end{array}$ \\
\hline 5 & $\begin{array}{l}\text { The items that presented divergence in the back-translation in comparison with the original document were highlighted by } \\
\text { the back-translator. }\end{array}$ \\
\hline 6 & Based on the comments of the back-translator, the authors designed a new synthesized version. \\
\hline 7 & $\begin{array}{l}\text { Four physical education teachers who work with children evaluated the items for clarity. The following scores were assigned: } \\
1 \text { - not clear; } 2 \text { - partly clear; } 3 \text { - totally clear. A mean for each of the } 59 \text { items was calculated. For validation purposes, } \\
\text { means between } 2.75 \text { and } 3 \text { were considered clear, between } 2 \text { and } 2.5 \text { partly clear, and below } 2 \text { not clear. }\end{array}$ \\
\hline 8 & Partly clear items were analyzed by a focus group composed of three other physical education teachers. \\
\hline 9 & The suggestions of the focus group were sent for approval by the author of the original version. \\
\hline 10 & The author's comments were analyzed to produce the final version. \\
\hline
\end{tabular}




\section{Results}

The comparison of the back-translated version with the original version (stage 4 ) revealed 38 items satisfactorily translated (68\%) and 18 divergent items $(32 \%)$, which were forwarded to the back-translator along with the original version for consideration. The back-translator considered nine of these items as semantically identical - and, therefore acceptable -, but made comments about the other nine items (Table $2)$, setting up stage 5 .

Taking into consideration the back-translator's comments, a further synthesized version of the instrument was produced (stage 6). The following stage, clarity assessment, revealed that $84.7 \%$ of the items were clear (36 items [61\%] had a mean score of 3 , and 14 items [23.7\%] had a mean of 2.75 ). Nine items were considered partially clear (3 [5\%] with a mean of $2.5,4$ [6.8\%] with a mean of 2.25 , and 2 [3.3\%] with a mean of 2 ).

The results of the analysis of the back-translated version with modifications as proposed by the focus group (stage 8) are shown in Table 3. Item 9 was considered clear by the focus group, and therefore required no alterations. Items 21 and 7 were modified in accordance with the focus group. The other items were kept according to the preliminary translated version, despite the modification suggestions.

\section{Discussion}

The cross-cultural adaptation and translation processes used in this article allowed the formulation

Table 2 - Comparison between the original version of the Motor Behavior Checklist and the translated and back-translated versions with semantic adaptation

\begin{tabular}{|c|c|c|c|c|}
\hline Item & Original version & Portuguese version & Back-translation to English & Back-translator's notes \\
\hline 2 & $\begin{array}{l}\text { Has difficulty } \\
\text { waiting his or her } \\
\text { turn to perform }\end{array}$ & $\begin{array}{l}\text { Tem dificuldade em } \\
\text { aguardar sua vez } \\
\text { para executar tarefas }\end{array}$ & $\begin{array}{l}\text { Has difficulty in taking turns } \\
\text { when executing tasks }\end{array}$ & $\begin{array}{l}\text { In "taking turns when executing tasks"/"waiting } \\
\text { his turn to perform," "executar tarefas" could be } \\
\text { translated as "perform" or "perform tasks" }\end{array}$ \\
\hline 33 & $\begin{array}{l}\text { May shift from } \\
\text { one uncompleted } \\
\text { activity to another }\end{array}$ & $\begin{array}{l}\text { Muda de uma } \\
\text { atividade inacabada } \\
\text { para outra }\end{array}$ & $\begin{array}{l}\text { Moves from one unfinished } \\
\text { activity to another }\end{array}$ & $\begin{array}{l}\text { Move/shift and unfinished/uncompleted are more } \\
\text { or less the same }\end{array}$ \\
\hline 42 & $\begin{array}{l}\text { Appears to be } \\
\text { driven by a motor }\end{array}$ & $\begin{array}{l}\text { Parece estar com um } \\
\text { motor ligado }\end{array}$ & $\begin{array}{l}\text { Seems to have their engine } \\
\text { running, seems to be over- } \\
\text { excited/hyperactive/full of } \\
\text { energy/over-stimulated }\end{array}$ & $\begin{array}{l}\text { In English, this phrase is vague, does not carry } \\
\text { meaningful information }\end{array}$ \\
\hline 11 & $\begin{array}{l}\text { Feels dizzy, } \\
\text { unsteady, light- } \\
\text { headed, or faint }\end{array}$ & $\begin{array}{l}\text { Sente tontura, } \\
\text { instabilidade, } \\
\text { fraqueza ou sensação } \\
\text { de desmaio }\end{array}$ & $\begin{array}{l}\text { Feels dizzy, unsteady, weak, } \\
\text { or faint }\end{array}$ & $\begin{array}{l}\text { "Weak, or faint"/"lightheaded, or faint" - "dizzy" } \\
\text { and "lightheaded" are very similar feelings. I } \\
\text { don't think there are two obviously equivalent } \\
\text { words in Portuguese; I think "sente tontura" } \\
\text { would be used for both }\end{array}$ \\
\hline 18 & $\begin{array}{l}\text { Displays low } \\
\text { energy }\end{array}$ & $\begin{array}{l}\text { Apresenta falta de } \\
\text { energia }\end{array}$ & Displays a lack of energy & $\begin{array}{l}\text { Lack/low - these are very close; I can't think of } \\
\text { anything better }\end{array}$ \\
\hline 13 & $\begin{array}{l}\text { Displays avoidance } \\
\text { of age-appropriate } \\
\text { social activities }\end{array}$ & $\begin{array}{l}\text { Evita atividades } \\
\text { sociais apropriadas } \\
\text { para sua idade }\end{array}$ & $\begin{array}{l}\text { Avoids age-appropriate social } \\
\text { activities }\end{array}$ & $\begin{array}{l}\text { "Avoids age..."/"Displays avoidance of age..." - } \\
\text { can you say "mostrar evitação"? }\end{array}$ \\
\hline 35 & $\begin{array}{l}\text { Displays lack to } \\
\text { communicate } \\
\text { with his or her } \\
\text { classmates }\end{array}$ & $\begin{array}{l}\text { Apresenta falta de } \\
\text { comunicação com } \\
\text { seus colegas de } \\
\text { classe }\end{array}$ & $\begin{array}{l}\text { Displays communication } \\
\text { problems with classmates }\end{array}$ & $\begin{array}{l}\text { "Displays communication problems with } \\
\text { classmates"/"Displays lack to communicate with } \\
\text { his or her classmates" }\end{array}$ \\
\hline 36 & $\begin{array}{l}\text { Fears standing in } \\
\text { a line }\end{array}$ & $\begin{array}{l}\text { Tem medo de ficar } \\
\text { em fila }\end{array}$ & $\begin{array}{l}\text { Afraid to stay in a queue } \\
\text { Has a fear of queuing }\end{array}$ & $\begin{array}{l}\text { "Afraid to stay in a queue"/"Has a fear of } \\
\text { queuing"/"Fears standing in a line" - this is } \\
\text { British English; "standing in line" sounds more } \\
\text { American, but the meaning is the same }\end{array}$ \\
\hline 54 & $\begin{array}{l}\text { Has difficulties } \\
\text { organizing group } \\
\text { activities }\end{array}$ & $\begin{array}{l}\text { Tem dificuldades } \\
\text { para organizar-se em } \\
\text { atividades de grupo }\end{array}$ & $\begin{array}{l}\text { Has difficulties (struggles) to } \\
\text { organize themselves in group } \\
\text { activities } \\
\text { Has difficulty taking part in } \\
\text { group activities }\end{array}$ & $\begin{array}{l}\text { There is a difference here. They seem to mean } \\
\text { the person has difficulties organizing the } \\
\text { activities, i.e., they are responsible for this as a } \\
\text { leader, and not that they have difficulty taking } \\
\text { part as a member of the group, not the organizer. } \\
\text { It does though seem a little strange; I would } \\
\text { expect the latter meaning here }\end{array}$ \\
\hline
\end{tabular}


of a Brazilian Portuguese version of the MBC that will enable physical education teachers to evaluate their student's behavioral aspects in sports and free-play situations. It will also contribute to the identification of emotional and behavioral problems related to some NDD highly prevalent among children and adolescents.

Detailed assessment by a team of professionals with multiple instruments can benefit proper identification of behavior changes and/or developmental delays. Therefore, we highlight the importance of the crosscultural adaptation of instruments for use in different countries, as demonstrated by previous works and performed in our study. ${ }^{11-13}$ In addition, evidence of validity should be demonstrated through multiple informants.

The translated and culturally adapted version of the $M B C$, as described in this article, should contribute to the development of another instrument for the assessment of children by physical education teachers or classroom teachers. Supported by such instruments, these professionals can provide reports on children's behaviors observed in natural conditions of interaction and competition, which are rarely considered in evaluation protocols.
Our results revealed a satisfactory level of agreement between the original and back-translated versions, with $68 \%$ of exact equivalence between the translated items and $16 \%$ of terms requiring minor adjustments. Clarity assessment using reports from physical education teachers revealed an $84 \%$ agreement with the draft version of the MBC. Consequently, the Brazilian Portuguese version of the instrument showed adequate indicators of semantic equivalence after the translation, back-translation, and clarity assessment by professionals and the focus group. The synthetized version of the instrument required a few modifications for semantic and cultural adequacy in relation to the original version.

The present study sought maximum equivalence between the original instrument and the translated version. Our results are in accordance with other studies that revealed that, based on the synthetized version, the translation and back-translation processes were adequate and without major distortions. ${ }^{17,18}$ After this adaptation stage with satisfactory results, assessment of the psychometric properties of the instrument can be conducted. ${ }^{19}$ A study currently in progress, by our group, has started to assess the psychometric

Table 3 - Modifications proposed by the focus group to the back-translated version of the Motor Behavior Checklist

\begin{tabular}{|c|c|c|c|c|}
\hline Item & Original version & $\begin{array}{l}\text { Preliminary translated } \\
\text { version }\end{array}$ & Focus group's suggestion & $\begin{array}{l}\text { Modifications post-focus } \\
\text { group }\end{array}$ \\
\hline 15 & $\begin{array}{l}\text { Is aggressive toward } \\
\text { leadership figures }\end{array}$ & $\begin{array}{l}\text { É agressivo em relação a } \\
\text { figuras de liderança }\end{array}$ & $\begin{array}{l}\text { É agressivo em relação a figuras } \\
\text { de liderança (professores e } \\
\text { colegas) }\end{array}$ & Maintained as translated \\
\hline 21 & $\begin{array}{l}\text { Is negative toward his or } \\
\text { her classmates }\end{array}$ & $\begin{array}{l}\text { É negativo em relação aos } \\
\text { seus colegas de classe }\end{array}$ & $\begin{array}{l}\text { The focus group was not able } \\
\text { to understand the item because } \\
\text { it was vague. They suggested } \\
\text { to check with the author of the } \\
\text { instrument }\end{array}$ & $\begin{array}{l}\text { É negativo em relação aos } \\
\text { seus colegas de classe (por } \\
\text { exemplo: comportamentos } \\
\text { fisicamente agressivos) }\end{array}$ \\
\hline 9 & $\begin{array}{l}\text { Displays hyperactivity } \\
\text { during lesson }\end{array}$ & $\begin{array}{l}\text { Apresenta hiperatividade } \\
\text { durante a aula }\end{array}$ & $\begin{array}{l}\text { Apresenta hiperatividade durante } \\
\text { a aula }\end{array}$ & Maintained as translated \\
\hline 42 & $\begin{array}{l}\text { Appears to be driven by a } \\
\text { motor }\end{array}$ & $\begin{array}{l}\text { Parece estar com um motor } \\
\text { ligado }\end{array}$ & Demonstra estar bastante agitado & Maintained as translated \\
\hline 24 & Shows decreased activity & $\begin{array}{l}\text { Mostra diminuição do nível } \\
\text { de atividade }\end{array}$ & $\begin{array}{l}\text { Mostra diminuição do nível de } \\
\text { atividade física ao longo da aula }\end{array}$ & Maintained as translated \\
\hline 6 & $\begin{array}{l}\text { Displays impairment in } \\
\text { gestures, which regulate } \\
\text { social interaction }\end{array}$ & $\begin{array}{l}\text { Apresenta } \\
\text { comprometimento em } \\
\text { gestos que regulam a } \\
\text { interação social }\end{array}$ & $\begin{array}{l}\text { Suggestion to exemplify which } \\
\text { gestures }\end{array}$ & Maintained as translated \\
\hline 19 & $\begin{array}{l}\text { Doesn't show objects he or } \\
\text { she finds interesting }\end{array}$ & $\begin{array}{l}\text { Não mostra objetos que } \\
\text { acha interessante }\end{array}$ & $\begin{array}{l}\text { Quando solicitado não aponta } \\
\text { objetos que acha interessante }\end{array}$ & Maintained as translated \\
\hline 25 & $\begin{array}{l}\text { Doesn't bring objects he or } \\
\text { she finds interesting }\end{array}$ & $\begin{array}{l}\text { Não traz objetos que acha } \\
\text { interessante }\end{array}$ & $\begin{array}{l}\text { Quando solicitado, não traz } \\
\text { objetos que acha interessante }\end{array}$ & Maintained as translated \\
\hline 7 & $\begin{array}{l}\text { Displays persistent } \\
\text { preoccupation with parts of } \\
\text { objects }\end{array}$ & $\begin{array}{l}\text { Apresenta preocupação } \\
\text { persistente com partes de } \\
\text { objetos }\end{array}$ & $\begin{array}{l}\text { Apresenta curiosidade persistente } \\
\text { com partes de objetos }\end{array}$ & $\begin{array}{l}\text { Apresenta interesse } \\
\text { persistente com partes de } \\
\text { objetos }\end{array}$ \\
\hline
\end{tabular}


properties of our translated version of the checklist. The aim of that study is to investigate whether the Brazilian Portuguese version of the MBC can be used as a valid and reliable assessment instrument by physical education teachers.

The Brazilian Portuguese version of the MBC was produced following rigorous translation and cross-cultural adaptation procedures and is presented in Appendix 1. Our instrument fills a gap in the evaluation process of students in sports and free-play situations. Moreover, it can help school teachers to better understand and effectively deal with their students' behavioral profiles, especially those with behavior problems compatible with NDD.

\section{Acknowledgements}

This study was supported in part by Coordenação de Aperfeiçoamento de Pessoal de Nível Superior (CAPES; financial support code 001) and CAPES PROEX (grant 0653/2018). The authors would like to thank Fundo Mackenzie de Pesquisa - Mackpesquisa for their additional financial support.

\section{Disclosure}

No conflicts of interest declared concerning the publication of this article.

\section{References}

1. Associação Americana de Psiquiatria. Manual Diagnóstico e Estatístico de Transtornos Mentais, $5^{a}$ edição (DSM-5). Porto Alegre: Artmed; 2014.

2. Lyra GFD, Assis SG de, Njaine K, Oliveira R de VC de, Pires TdeO. A relação entre professores com sofrimento psíquico e crianças escolares com problemas de comportamento. Cienc Saude Coletiva. 2009;14:435-44.

3. Bordin IA, Rocha MM, Paula, CS, Teixeira MCTV, Achenbach TM, Rescorla LA, et al. Child Behavior Checklist (CBCL), Youth SelfReport (YSR) and Teacher's Report Form (TRF): an overview of the development of the original and Brazilian versions. Cad Saude Publica. 2013;29:13-28.

4. Hanssen-Bauer K, Langsrud $\varnothing$, Kvernmo S, Heyerdahl S. Clinicianrated mental health in outpatient child and adolescent mental health services: associations with parent, teacher and adolescent ratings. Child Adolesc Psychiatry Ment Health. 2010;4:29.

5. Gooch D, Maydew H, Sears C, Norbury CF. Does a child's language ability affect the correspondence between parent and teacher ratings of ADHD symptoms? BMC Psychiatry. 2017;17:129.

6. Efstratopoulou M, Janssen R, Simons J. Assessing children at risk: psychometric properties of the Motor Behavior Checklist. J Atten Disord. 2015;19:1054-63.

7. Johnson RC, Rosén LA. Sports behavior of ADHD children. J Atten Disord. 2000;4:150-60.

8. Clendenin AA, Businelle MS, Kelley ML. Sports Behavior Checklist: factor structure, convergent and divergent validity, and screening ADHD problems in the group differences. J Atten Disord. 2005; 8:79-87.

9. Efstratopoulou M, Janssen R, Simons J. Differentiating children with attention-deficit/hyperactivity disorder, conduct disorder, learning disabilities and autistic spectrum disorders by means of their motor behavior characteristics. Res Dev Disabil. 2012;33:196-204.

10. Efstratopoulou M, Janssen R, Simons J. Agreement among physical educators, teachers and parents on children's behaviors: a multitrait-multimethod design approach. Res Dev Disabil. 2012;33:1343-51.

11. Borsa JC, Damasio BF, Bandeira DR. Adaptação e validação de instrumentos psicológicos entre culturas: algumas considerações. Paideia. 2012;22:423-32.

12. Gjersing L, Caplehorn JR, Clausen T. Cross-cultural adaptation of research instruments: language, setting, time and statistical considerations. BMC Med Res Methodol. 2010;10:13.

13. International Test Commission. The ITC guidelines for translating and adapting tests (second edition) [Internet]. 2017 [cited 2018 Mar 21]. https://www.intestcom.org/files/guideline_test_ adaptation_2ed.pdf

14. Mondrzak $\bar{R}$, Reinert $C$, Sandri A, Spanemberg L, Nogueira EL, Bertoluci $M$, et al. Translation and cross-cultural adaptation of the Rating Scale for Countertransference (RSCT) to American English. Trends Psychiatry Psychother. 2016;38:4.

15. Conti MA, Scagliusi F, Queiroz GK de O, Hearst N, Cordás TA. Adaptação transcultural: tradução e validação de conteúdo para o idioma português do modelo da Tripartite Influence Scale de insatisfação corporal. Cad Saude Publica. 2010;26:503-13.

16. Mattos $P$, Segenreich D, Saboya E, Louzã M, Dias G, Romano M. Adaptação transcultural para o português da escala Adult Self-Report Scale para avaliação do transtorno de déficit de atenção/hiperatividade (TDAH) em adultos. Rev Psiquiatr Clin. 2006;33:188-94.

17. Giusti E, Befi-Lopes DM. Tradução e adaptação transcultural de instrumentos estrangeiros para o português brasileiro (PB). PróFono Rev Atual Cient. 2008;20:207-10.

18. Pasquali L. Validade dos testes psicológicos: será possível reencontrar o caminho? Psic Teor Pesq. 2007;23:99-107.

19. Alexandre NMC, Coluci MCO. Content validity in the development and adaptation processes of measurement instruments. Cienc Saude Coletiva. 2011;16:3061-8.

\section{Correspondence:}

Ronê Paiano

Centro de Ciências Biológicas e da Saúde, Universidade Presbiteriana Mackenzie

Rua da Consolação, 896, prédio 28, $1^{\circ}$ andar, Consolação

01302-000 - São Paulo, SP - Brazil

Tel./Fax: +55 (11) 2114-8707

E-mail: rone.pefe@gmail.com 


\title{
Appendix 1
}

\author{
INVENTÁRIO DE COMPORTAMENTO MOTOR - MBC \\ Versão brasileira do "Motor Behavior Checklist (MBC)" \\ Efstratopoulou, M., Janssen, R. \& Simons J. (2015)
}

Instrumento traduzido e adaptado por Ronê Paiano; Maria Cristina Triguero Veloz Teixeira; Carla Nunes Cantiere; Maria Efstratopoulou; Luiz Renato Rodrigues Carreiro

Nome da criança:

Data de Nascimento:

Data da aplicação:

Nome da Escola:

Ano Escolar:

Nome do professor:

Abaixo há uma lista de itens que descrevem comportamentos motores de crianças durante a aula de educação física e tempo de lazer. Por favor, leia cuidadosamente cada comportamento e circule cada número correrspondete a sua resposta, usando as opções: $0=$ nunca; 1 = às vezes; $2=$ frequentemente; $3=$ muito frequentemente e $4=$ quase sempre. Responda a todas as questões mesmo que algumas não pareçam se aplicar a criança em avaliação.

Não deixar nenhum item sem ser circulado.

\begin{tabular}{|c|c|c|c|c|c|}
\hline & $\begin{array}{l}\text { U } \\
\stackrel{5}{Z} \\
z\end{array}$ & 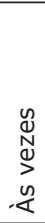 & 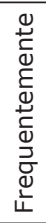 & 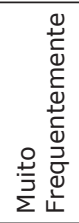 & 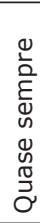 \\
\hline 1. Não segue regras, especialmente em situação de jogo & 0 & 1 & 2 & 3 & 4 \\
\hline 2. Tem dificuldade em aguardar sua vez para executar tarefas & 0 & 1 & 2 & 3 & 4 \\
\hline 3. É descuidado & 0 & 1 & 2 & 3 & 4 \\
\hline 4. Apresenta cansaço, até mesmo, após um mínimo de esforço & 0 & 1 & 2 & 3 & 4 \\
\hline $\begin{array}{l}\text { 5. Apresenta movimentos corporais estereotipados, que incluem as mãos (por } \\
\text { exemplo, bater palmas, estalar os dedos) }\end{array}$ & 0 & 1 & 2 & 3 & 4 \\
\hline 6. Apresenta comprometimento em gestos que regulam a interação social & 0 & 1 & 2 & 3 & 4 \\
\hline 7. Apresenta interesse persistente com partes de objetos & 0 & 1 & 2 & 3 & 4 \\
\hline 8. Apresenta desobediência para com seu professor & 0 & 1 & 2 & 3 & 4 \\
\hline 9. Apresenta hiperatividade durante a aula & 0 & 1 & 2 & 3 & 4 \\
\hline 10. Tem dificuldade de concentração & 0 & 1 & 2 & 3 & 4 \\
\hline 11. Sente tontura, instabilidade, fraqueza ou sensação de desmaio & 0 & 1 & 2 & 3 & 4 \\
\hline 12. Apresenta padrões repetitivos de atividades & 0 & 1 & 2 & 3 & 4 \\
\hline 13. Evita atividades sociais apropriadas para sua idade & 0 & 1 & 2 & 3 & 4 \\
\hline 14. Não mostra interesse pela aula & 0 & 1 & 2 & 3 & 4 \\
\hline 15. É agressivo em relação a figuras de liderança & 0 & 1 & 2 & 3 & 4 \\
\hline 16. Interrompe os outros (por exemplo, intromete-se em conversa) & 0 & 1 & 2 & 3 & 4 \\
\hline 17. Tem dificuldade em manter a atenção em tarefas & 0 & 1 & 2 & 3 & 4 \\
\hline 18. Apresenta falta de energia & 0 & 1 & 2 & 3 & 4 \\
\hline 19. Não mostra objetos que acha interessante & 0 & 1 & 2 & 3 & 4 \\
\hline $\begin{array}{l}\text { 20. Apresenta prejuízo marcante no uso de comportamentos não-verbais } \\
\text { (contato olho-no-olho) }\end{array}$ & 0 & 1 & 2 & 3 & 4 \\
\hline $\begin{array}{l}\text { 21. É negativo em relação aos seus colegas de classe (por exemplo } \\
\text { comportamentos fisicamente agressivos) }\end{array}$ & 0 & 1 & 2 & 3 & 4 \\
\hline 22. Interrompe os outros (por exemplo, intromete-se em jogos) & 0 & 1 & 2 & 3 & 4 \\
\hline 23. Parece que não escutou o que acabou de ser dito & 0 & 1 & 2 & 3 & 4 \\
\hline 24. Mostra diminuição do seu nível de atividade & 0 & 1 & 2 & 3 & 4 \\
\hline 25. Não traz objetos que acha interessante & 0 & 1 & 2 & 3 & 4 \\
\hline 26. Apresenta prejuízo na expressão facial & 0 & 1 & 2 & 3 & 4 \\
\hline 27. Culpa os outros por seus erros & 0 & 1 & 2 & 3 & 4 \\
\hline
\end{tabular}




\begin{tabular}{|c|c|c|c|c|c|}
\hline & $\begin{array}{l}\text { Uु } \\
\frac{\mathrm{C}}{2} \\
z\end{array}$ & 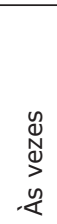 & 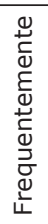 & 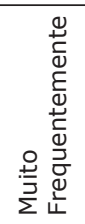 & 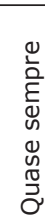 \\
\hline 28. Não cuida dos equipamentos & 0 & 1 & 2 & 3 & 4 \\
\hline $\begin{array}{l}\text { 29. Evita ou tem uma forte antipatia por atividades que exigem extrema } \\
\text { concentração }\end{array}$ & 0 & 1 & 2 & 3 & 4 \\
\hline 30. Evita contato com outras pessoas & 0 & 1 & 2 & 3 & 4 \\
\hline 31. Não reconhece o seu medo como excessivo & 0 & 1 & 2 & 3 & 4 \\
\hline 32. Joga bruto demais durante os jogos da equipe & 0 & 1 & 2 & 3 & 4 \\
\hline 33. Muda de uma atividade inacabada para outra & 0 & 1 & 2 & 3 & 4 \\
\hline 34. Apresenta dificuldade de concentração no início da aula & 0 & 1 & 2 & 3 & 4 \\
\hline 35. Apresenta falta de comunicação com seus colegas de classe & 0 & 1 & 2 & 3 & 4 \\
\hline 36. Tem medo de ficar em fila & 0 & 1 & 2 & 3 & 4 \\
\hline 37. Apresenta tendência a cometer bullying com seus colegas de classe & 0 & 1 & 2 & 3 & 4 \\
\hline 38. Envolve-se em atividades perigosas sem considerar possíveis consequências & 0 & 1 & 2 & 3 & 4 \\
\hline 39. Tem dificuldades para organizar tarefas & 0 & 1 & 2 & 3 & 4 \\
\hline 40. É isolado pelos seus colegas de classe & 0 & 1 & 2 & 3 & 4 \\
\hline $\begin{array}{l}\text { 41. Apresenta ansiedade que pode se expressar por choro, ataques de raiva, } \\
\text { imobilidade ou se agarrar. }\end{array}$ & 0 & 1 & 2 & 3 & 4 \\
\hline 42. Parece estar com um motor ligado & 0 & 1 & 2 & 3 & 4 \\
\hline 43. Comete erros por descuido em atividades & 0 & 1 & 2 & 3 & 4 \\
\hline 44. Procura manter-se próximo a adultos familiares & 0 & 1 & 2 & 3 & 4 \\
\hline 45. Apresenta dificuldade em tomar decisões & 0 & 1 & 2 & 3 & 4 \\
\hline $\begin{array}{l}\text { 46. Tem dificuldade para jogar ou envolver-se silenciosamente em atividades de } \\
\text { lazer }\end{array}$ & 0 & 1 & 2 & 3 & 4 \\
\hline 47. Falha em prestar atenção a detalhes & 0 & 1 & 2 & 3 & 4 \\
\hline 48. Não quer contato físico & 0 & 1 & 2 & 3 & 4 \\
\hline 49. Acha difícil controlar preocupações & 0 & 1 & 2 & 3 & 4 \\
\hline 50. Fica chateado quando perde & 0 & 1 & 2 & 3 & 4 \\
\hline 51. Não participa ativamente nas brincadeiras sociais simples & 0 & 1 & 2 & 3 & 4 \\
\hline 52. Fica chateado quando não consegue completar uma tarefa & 0 & 1 & 2 & 3 & 4 \\
\hline 53. Superestima suas capacidades & 0 & 1 & 2 & 3 & 4 \\
\hline 54. Tem dificuldades para organizar atividades de grupo & 0 & 1 & 2 & 3 & 4 \\
\hline 55. Evita ou tem uma forte antipatia por atividades que exigem organização & 0 & 1 & 2 & 3 & 4 \\
\hline 56. Apresenta comportamento impulsivo & 0 & 1 & 2 & 3 & 4 \\
\hline 57. Mexe em coisas que não são para mexer & 0 & 1 & 2 & 3 & 4 \\
\hline 58. Apresenta pouca variedade nas brincadeiras de faz-de-conta & 0 & 1 & 2 & 3 & 4 \\
\hline 59. Perde a calma & 0 & 1 & 2 & 3 & 4 \\
\hline
\end{tabular}

\section{Confira se todas as perguntas foram respondidas. Obrigado pela sua participação!}

Efstratopoulou, M., Janssen, R. \& Simons J. (2015). Assessing Children at Risk: Psychometric Properties of the Motor Behavior Checklist. J Atten Disord. Dec;19(12):1054-63. doi: 10.1177/1087054713484798.

Efstratopoulou, M. (2014). Working with challenging children: From theory to practice in primary education. Novinka, New York. 